\title{
Overcoming Communicative Deadaptation of Speech Passive Children of Pre-School Age
}

\section{Подолання комунікативної дезадаптації у мовленнєво пасивних дітей дошкільного віку}

\section{Larysa Zdanevych ${ }^{1}$ \\ Dr. in Pedagogy, Professor, \\ Head of the Department of Pre-School Pedagogy,}

Psychology and Professional Methods

\author{
Лариса Зданевич ${ }^{1}$ \\ доктор педагогічних наук, \\ професор, завідувач кафедри \\ дошкільної педагогіки, \\ психології та фахових методик
}

E-mail: larisazdan@ukr.net orcid.org/0000-0001-8387-2143

Kateryna Kruty ${ }^{2}$

Dr. in Pedagogy, Professor
Катерина Крутій

доктор педагогічних наук, професор

\section{E-mail: katerina.krutiy@gmail.com orcid.org/0000-0001-5001-2331}

${ }^{1}$ Khmelnytskyi Humanitarian-

Pedagogical Academy

139, Proskurivskoho pidpillia Str.,

Khmelnytskyi, Ukraine, 29000

${ }^{2}$ Vinnytsia Mykhailo Kotsiubynskyi

State Pedagogical University

32, Ostrozkoho Str., Vinnytsia, Ukraine, 21100

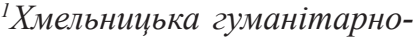
педагогічна академія

вул. Проскурівського підпілля, 139, Хмельницький, Україна, 29000

${ }^{2}$ Вінницький державний педагогічний університет імені Михайла Коияюбинського $\checkmark$ вул. Острозького, 32, Вінниця, Україна, 21100

Original manuscript received February 19, 2019

Revised manuscript accepted October 01, 2019 


\section{ABSTRACT}

Introduction. The article analyzes the child's speech concerning the individual peculiarities. It is about the formation of the communicative competence of the child. It is revealed that this process involves aspects: the acquisition of skills in the systemlanguage and directly in the communicative spheres.

Objectives - to structure theoretical developments of the problem under research, to emphasize their contribution into general approaches to speech activity of pre-school children, to single out groups of speech-passive children on the basis of communicative deadaptation.

Research methods and techniques. The typological groups of speech-passive children have been singled out: "operational-technical», "motivational», "partial» or "selective» speech passivity. The experimental research on the identification of speech-passive children has been planned and carried out. The Heidelberger Speech Development Test has been used to diagnose the speech abilities of children aged 3 to 9 and a questionnaire for assessing speech and cognitive development of the child. Results and discussions. The child's individual speech is understood as a socially and biologically conditioned system of sign psychic configurations, used by the individual both for thinking and for speech communication, which can be both active and passive. The possibilities of using the results of modern interdisciplinary researches to identify communicative maladaptation of senior pre-school children, who are speechpassive, have been revealed. The speech activity of children is defined as a stable personality property, which manifests itself in the ability to perceive and understand the speech of others. The speech passivity of the child is understood as a lower level of speech activity, due to the peculiarities of speech development in ontogenesis. Active and inert types of speech have been characterized. It is concluded that the age of five years has a special significance for onto-psycholinguistic researches. This age is characterized by the crisis of egocentric speech, culminating in its internalization, accompanied by the general communicative maladaptation.

Conclusions. It is proved that the violation of the process of communication of speechpassive pre-schoolers is manifested mainly in two varieties, as communicative deficit or communicative exaltation.

Key words: children of pre-school age, speech passiveness, speech activity, communicative maladaptation, communicative deficit, communicative exaltation, speech and cognitive development of a child.

\section{Вступ}

Відповідно до традиційних уявлень науковців, які працюють у царині лінгвістики, психолінгвістики, онтолінгвістики оволодіти мовою означає опанувати не лише формальною та змістовою стороною іiі одиниць, а й функціями, 3 якими ці одиниці 
використовуються в мові, головним чином, в первинній для дитини формі існування мови - розмовному діалозі.

Йдеться про становлення комунікативної компетенції дитини. Цей процес охоплює, як мінімум, два аспекти: надбання навичок у системно-мовній і власне комунікативній сферах. Обсяг системномовної компетенції визначається реальністю самої мови. Вочевидь, що під час вивчення багатоманітності індивідуального мовлення дитини, як і багатоманітності в будь-якій іншій сфері дослідження, певну користь могла б дати класифікація, диференціація і характеристики за типами, критеріями та ін., якщо вони можливі. Індивідуальне мовлення дитини розуміється нами як соціально i біологічно обумовлена система знакових психічних конфігурацій, використана індивідом як для мислення, так i для мовленнєвого спілкування, яке може бути як активним, так i пасивним (Крутій, 2003).

Визначаючи активність як особливу форму діяльності, дослідники в той же час вказують на їх відмінності. К.А. Абульханова-Славська відмінності бачить у тому, що «діяльність» виходить 3 потреби в предметі, а «активність» - 3 потреби в діяльності (Альбуханова-Славская, 1991). Розходження цих понять, на думку I.O. Джидарьян (1988), в тому, що активність належить безпосередньо суб'єкту, а діяльність спрямована на об’єкт. У категорії «активність» основний акцент припадає на джерела, причини взаємодії, спонтанність, мимовільність суб’єкта, а в категорії «діяльність» увага приділяється операційнодинамічній стороні взаємодії та відносної статичності. Різницю цих понять досліджували О.О. Волочков (2003) та ін. Активність особистості може бути потенційною (стан прагнення та готовності до діяльності) i реальною (зреалізована готовність i прагнення, у результаті чого й досягається поставлена мета). Отже, активність є вищим рівнем розвитку, вона спонукає людину до діяльності, в ході якої реалізуються і вдосконалюються особистісні якості. У сучасній філософії, психології та педагогіці існує три підходи до пояснення сутності понять «активність» i «діяльність»: одні дослідники розглядають активність ширше, ніж діяльність (Выготский, 1996; Рубинштейн, 2000), інші ставлять між цими поняттями знак рівності (Леонтьев, 2003) та ін., а треті активність розглядають як характеристику діяльності (Ковалев, 1970; Фельдштейн, 
1999 та ін.). Ми дотримуємось психолого-педагогічного підходу О.Г. Ковальова, який підкреслював важливість розвитку активності дитини. Науковцем активність визначається як діяльнісне ставлення особистості до світу, здатність проводити суспільно значущі перетворення матеріального та духовного середовища на основі освоєння історичного досвіду людства (Ковалев, 1970).

Аналіз міжнародних науково-метричних баз Scopus, Web of Science та Google Scholar щодо вивчення наукових публікацій у руслі заявленої нами теми, дає підстави стверджувати, що проблема мовленнєвої пасивності дітей дошкільного віку в контексті психолінгвістичних досліджень заявляється вперше. Дотичним до нашого дослідження є монографія Foster-Cohen, Susan H. (2014). Авторка демонструє необхідність як розвитку теорії мовлення, так і надійних даних щодо досліджень розуміння мовлення дитини. На думку дослідниці, прийняття тільки одного підходу, на відміну від поєднання різних підходів, навряд чи призведе до продуктивного розуміння стратегій оволодіння мовою дитиною. Цікаві підходи до вивчення активного мовлення дітей було зафіксовано в роботах (Ahmadian, 2016; Lanvers, 2017).

Дослідники відзначають, що й дотепер недостатньо вивчено механізми і причини пасивності в мовленнєвій діяльності дітей, яка в подальшому може бути чинником комунікативної дезадаптації в соціумі.

Мета статmi - структурувати теоретичні розробки досліджуваної проблеми, акцентувати їх внесок у загальні підходи до мовленнєвої активності дошкільників, виокремити групи мовленнєвопасивних дітей за ознакою комунікативної дезадаптації.

\section{Методи та методики дослідження}

Використаний нами Гейдельберзький тест мовленнєвого розвитку (Heidelberger Sprachentwicklungs Test, 1978) було спрямовано на діагностику мовленнєвих здібностей дітей у віці від 3 до 9 років (адаптовано в Україні К.Л. Крутій у 2005 році). Пристосування, модифікація й адаптація Гейдельберзького мовленнєвого тесту дозволила вивчити майже всі компоненти багатопланової структури мовленнєвої здібності (або іï відсутності) 
у старших дошкільників. Тест містить батарею субтестів: розуміння граматичних структур (ГС); утворення однини - множини іменників (MO); імітація граматичних структур (ІГ); корекція семантично невірних речень (КС); словотвір (СТ); варіації назв (BН); класифікація понять (КП); розповідь для запам'ятовування (О3); утворення ступенів порівняння прикметників (ПП); взаємозв'язок вербальної та невербальної інформації (BНI); кодування і декодування наявної інтенції (КД); конструювання речень (КР); знаходження слів (ЗС).

Доповненням до обстеження стану мовлення дітей було використання опитувальника для очінки мовленнєвого $і$ когнітивного розвитку дитини (автор О.С. Ляксо), а саме: комунікація всередині групи (Ушакова, 2008).

Методика роботи з тестом передбачала: збір матеріалу, безпосереднє спостереження за поведінкою дітей без втручання 3 боку дорослого; опосередковане спостереження, що припускає використання матеріалів спостережень, проведених іншими людьми (вихователями, які проводять 3 дитиною спеціалізовані мовленнєві заняття); експериментальне дослідження: створення комунікативних ситуацій взаємодії дітей із дорослими і між собою; читання книг i розглядання картинок; малювання; рахунок; різноманітні освітні ситуації; додатково було використано метод інтерв'ю з батьками дитини. Заповнення тесту: напроти зазначеного параметра в графі ставився знак «+» у разі позитивної відповіді, «-» у разі негативної відповіді.

Обробка даних передбачала оцінку всіх можливостей дитини і здійснювалася за допомогою бальної системи. Значущі відмінності між показниками виконання різних видів субтестів установлювалися за допомогою процедури однофакторного дисперсійного аналізу комп'ютерного забезпечення Microsoft Excel. Розгляд результатів кореляційного аналізу свідчить про те, що використана методика показує явну картину мовленнєвої активності/пасивності дітей старшого дошкільного віку. Адаптація опитувальника. У дослідженні брали участь 68 дітей, які відвідують заклади дошкільної освіти № 50 та 72 м. Вінниця. Для заповнення всіх пунктів опитувальника роботу 3 кожною дитиною проводили впродовж 3-4 днів. На цьому етапі роботи для перевірки того, наскільки повно показники, включені в опитувальник, відображають 
рівень розвитку дитини, нами для подальшого аналізу було здійснено запис дітей: їх спілкування один із одним, вихователем, експериментатором. Час запису відео- i аудіозаписи становив 60-90 хв. У процесі взаємодії дітям ставились також запитання 3 певних тем: про іграшки, улюблені заняття, природу, родину тощо.

\section{Результати та дискусії}

Досліджуючи лінгводидактичні проблеми навчання дошкільників мови, К.Л. Крутій пропонує таке визначення: мовленнєва активність дітей - це стійка властивість особистості, що виявляється в здатності сприймати і розуміти мовлення оточуючих; самостійному, різноманітному, ініціативному використанні мовлення в практиці спілкування; активному оволодінні мовою (Крутій, 2003). Комунікативні проблеми дошкільників яскраво виявляються в процесі взаємодії 3 однолітками і дорослими, у спільній навчальній та побутовій діяльності, партнерській грі, в ситуаціях нерегламентованого спілкування. Проблеми входження в дитячі спільноти, недостатні навички враховувати у спільній діяльності комунікативні інтереси однолітків призводять до збіднення мовленнєвого досвіду дитини, негативно впливають на характер i зміст лінгвістичних ігор. Зазначимо, що проміжок часу від середнього до старшого дошкільного віку $є$ періодом формування найважливішого психологічного новоутворення - мовленнєвої діяльності, оформляється перехід до внутрішнього мовлення, як носія функції планування, яке обумовлює виникнення процесу інтеріоризації дій, абстрагування їх ознак і властивостей. Проблеми в налагодженні комунікації, пасивність або негативізм призводять до затримки своєчасної появи вікових новоутворень. Названі проблеми можуть поєднуватись із порушенням емоційно-вольової сфери, розладами комунікації i, як наслідок, 3 комунікативної дезадаптацією (Зданевич, 2013).

Отже, протилежністю «активності» $є$ «пасивність». У мовознавстві синонімами до слова пасивний є: неактивний, недіяльний, байдужий, безініціативний, бездільний, інертний, i навіть сонний. У психології пасивність розглядається як параметр характеристики особистості - байдужий, залежний, несамостійний, 
що не виявляє діяльності; як категорія визначає якість активності, ii міру. Кожному рівню розвитку особистості властива своя специфічна активність, але те, що для одного рівня може бути визначене як активність, стосовно іншого рівня може розглядатися як щось пасивне (Джидарьян, 1988).

На основі вчення І.П. Павлова про типи вищої нервової діяльності, 3 усієї багатоманітності мовлення i мовців науковці насамперед виокремлюють за станом мовленнєвої активності два основних типи: 1) сильний, урівноважений, що характеризується активним володінням мовленням; 2) слабкий, інертний, гальмівний у мовленні (Русанівський, 1972).

Активний тип мовлення передбачає безперешкодну, без рис гальмування, динаміку процесу мовлення у психіці (урівноважену, нормальну збуджувану), коли пам'ять у належному темпі «подає» слово, речення, асоціацію у відповідь на зовнішнє чи внутрішнє рефлекторне подразнення, збудження, сприйняття. Інертний тип мовлення має свої специфічні різновиди, діапазон яких чималий (Русанівський, 1972). Власне інертність мовлення полягає у несловоохочості, мовчазності, скупості на слова. Свідоме i цілеспрямоване вживання цього типу мовлення дорослою людиною свідчить про певну манеру мовлення - неактивну, пасивну, про певну особливість темпераменту. Різновидом інертного мовлення $\epsilon$ гальмівне. Воно полягає в нерозумінні вжитих слів, перекрученні їх форм, конструкцій речень, в побоюванні висловитися.

Усе це може бути спричинене незадовільною мовною освітою, неувагою до свого мовлення. Але ці положення торкаються мовлення дорослої людини. Сучасний психолінгвіст I.Н. Горєлов доводить необхідність створення певних типологічних груп дітей, які в мовленнєвому спілкуванні можуть бути вибірково контактними, вибірково комунікабельними (Горелов \& Седов, 1998).

Проблема мовленнєвої пасивності (гальмування у мовленні) при збільшенні кількості дітей, котрі мають мовленнєві вади і підпадають під категорію або «дітей 3 особливими потребами», або «з низьким рівнем розвитку», або «особливостями в навчанні» сьогодні $\epsilon$ достатньо гострою й актуальною. Окремої уваги заслуговують дошкільники, які мають порушення певної функції, а саме - мовленнєвої. 
Під мовленнєвою пасивністю дитини розуміємо знижений рівень мовленнєвої діяльності, зумовлений особливостями мовленнєвого розвитку в онтогенезі, який проявляється в недостатній сформованості мовленнєвих умінь або у негативному ставленні до мовленнєвої діяльності зокрема, або у використанні обхідних шляхів під час виконання мовленнєвих вправ, завдань тощо. Відмежовуємо поняття «мовленнєва пасивність» від «мовленнєвого негативізму» (Крутій, 2003: 320). Мовленнєвий негативізм - це передусім категорична відмова дитини від спілкування, яке частіше за все спостерігається у дітей-логопатів.

Під мовленнєвим розвитком дитини дошкільного віку ми розуміємо наявність оптимального щодо віку кола лінгвістичних уявлень, мовленнєвих умінь i навичок, розвиненість мовлення, сформованість мовленнєвої активності, самостійність в оволодінні лінгвістичною інформацією, вміння використовувати різноманітні засоби спілкування (Крутій, 2003).

Індивідуальний мовленнєвий розвиток підпорядковується загальній закономірності - він перебуває під впливом двох головних взаємодіючих факторів - внутрішнього (програма спадковості) i зовнішнього (навколишнє середовище). Згідно із сучасними уявленнями, норма розвитку - це не тільки кількісна, але й, передусім, якісна оцінка особливостей функціонування організму, що забезпечує його пристосування до умов зовнішнього середовища. Особливе значення для онтопсихолінгвістичних досліджень має вік п’яти років. Цей вік характеризується кризою егоцентричного мовлення, що завершується його інтеріоризацією; пік мовленнєвої експресії зі значним збільшенням кількості граматичних помилок, неправильного вживання слів, порушень у структурі речень, утрудненнями в плануванні висловлювання, темповими розладами в умовах другої мовленнєвої кризи, що супроводжується у цілому комунікативною дезадаптацією (Мастюкова, 1981). На думку О.В. Трошина (2000), комунікативна дезадаптація найчастіше проявляється в період вікових мовленнєвих криз при формуванні психологічного новоутворення комунікативної системи. Отже, саме у віці п'яти років найбільш яскраво простежуються прояви комунікативної дезадаптації. Комунікативна дезадаптаџія дитини дошкільного віку - це порушення психологічних механізмів пристосування емоційно-особистісної сфери індивідуальності, 
особливостей мовленнєвомисленнєвих процесів і мовленнєвої діяльності до нових умов міжособистісного спілкування, соціальної ситуації розвитку (Зданевич, 2013). Комунікативна дезадаптація дитини проявляється в слабо сформованих навичках, пов'язаних із функціонуванням мовних засобів у реальному спілкуванні. 3 одного боку, до них входять навички, що забезпечують репліцирування i дотримання принципу кооперації (загальні діалогічні навички), 3 іншого боку, проблеми в створенні певного типу діалогічної єдності обумовлено структурно-семантичними і функціональними особливостями відповідної ініціативної репліки (часткові діалогічні навички). Л.О. Калмикова зазначає, що саме сформованість цих навичок дає можливість здійснювати обмін репліками, враховувати фактор адресата, ініціювати різні типи питальних, спонукальних, констатувальних реплік і адекватним чином, тобто враховуючи семантичну i граматичну когерентність, реагувати на них (Калмикова, 2009). Дослідження корпусу даних дитячого мовлення (щоденникові записи О.М. Гвоздєва та ін.) показали, що при загальному паралелізмі розвитку системно-мовного і діалогічного компонентів комунікативної компетенції на ранньому етапі мовного онтогенезу може спостерігатися їх дивергенція (Ушакова, 2008).

Саме прояви мовленнєвої пасивності дитини п'ятирічного віку $є$ показником наявності комунікативної дезадаптації. За Л.І. Бєляковою (Белякова, 1992), криза в розвитку мовлення дитини дошкільного віку характеризується вираженим мовленнєвим перенапруженням, порушеннями мовленнєвого дихання, утрудненнями в лексико-граматичному оформленні та програмуванні висловлювання. Порушення процесу спілкування також супроводжуються виникненням конкурентного і нестійкого типів комунікації з однолітками, зменшенням числа просоціальних форм поведінки, тобто комунікативною дезадаптацією (Смирнова, 1989). На думку О.Ю. Медвєдєвої, це визначає необхідність створення нових психодіагностичних та психокорекційних програм для дітей із позиції багаторівневого аналізу (Медведева, 2003).

У своєму дослідженні ми спирались на визначення B.I. Слободчикова, що «норма - це не щось середнє, що $\epsilon$, а те краще, що можливо в конкретному віці для конкретної дитини за відповідних умов» (Слободчиков, 2010) та на думку О.О. Леонтьєва, який зазначає, що «імпліцитна норма, яка існує у вигляді 
імпліцитного знання мовця про те, як йому «можна» i «треба» говорити (або, навпаки, як йому говорити не слід), виражена i в зовнішніх формах, що задана мовцю у вигляді експліцитного правила, яке він повинен засвоїти і виконання якого він повинен свідомо контролювати (Леонтьев, 2003). Саме така норма називається експліцитною нормою. Термін «мова особистості» було введено у науковий обіг саме О.О. Леонтьєвим, який обстоював думку, що важливим $є$ розуміння особистісно детермінованих стратегій мовленнєвого спілкування та оволодіння мовою, мови як смислового, а не лише значеннєвого феномена...» (Леонтьев, 2005). Для нас ці висновки надали можливість спланувати i здійснити експериментальне дослідження щодо виявлення мовленнєвопасивних дітей.

Як відомо, труднощі в спілкуванні можуть залежати від багатьох обставин, у своїй більшості вони зумовлені недостатньою (або несвоєчасною) сформованістю функціональних систем психіки дитини (Крутій, 2003) або окремих мовленнєвих функцій чи виду мовленнєвої діяльності (Kalmykova, 2015). Науковці виокремлюють дві основні причини, що ведуть до такої несформованості. Перша з цих причин пов'язана із середовищуем, в якому відбувається формування дитини. У цьому випадку може виникнути відповідна «незрілість» психічних процесів. Таке відставання може бути наслідком негативного мовленнєвого впливу оточуючих дорослих. Друга причина пов'язана зі специфікою визрівання мозку дитини. Індивідуальні особливості нерівномірного розвитку окремих відділів мозку, наявність незначних відхилень у роботі цих відділів можуть у подальшому негативно вплинути на формування функціональних систем, що забезпечують певні функції (пам'ять, мислення, мовлення).

Не підлягає сумніву той факт, що прояви мовленнєвої активності/пасивності залежать, насамперед, від потреби в спілкуванні. Ця потреба $є$ рушійною силою розвитку мовленнєвої діяльності. На кожному етапі розвитку дитини потреба в спілкуванні постає як потреба в участі дорослого. Процес спілкування (комунікативна функція мовлення) дитини з дорослим залежить від того, як складаються їхні взаємини, чи існують між ними емоційні зв’язки, емоційний контакт. 
Отже, необхідна відповідність між педагогічними вимогами до мовлення дитини i iï можливостями, зокрема й на рівні функціонування нервової системи. Практика роботи 3 дітьми дошкільного віку доводить, що саме контроль частіше за все $\epsilon$ найбільш слабким місцем у регуляції мовленнєвої діяльності дитини.

3 погляду комунікативної теорії, розлад мовлення $\epsilon$ порушенням вербальної комунікації. Обмеженість словникового запасу в дітей розглядається як один 3 визначальних факторів, що перешкоджають їхньому спілкуванню. Формою реалізації активності виступає діяльність. М.С. Каган, розглядаючи діяльність як «активність суб'єкта, спрямовану на світ об'єктів у взаємодії 3 іншими суб'єктами» (Каган, 1974), виокремлює різні види діяльності: перетворювальну, пізнавальну, комунікативну тощо. Кожен вид діяльності має свій предметний зміст. Отже, видів активності буде стільки, скільки існуе видів діяльності. Залежно від реалізації активності в тому чи іншому виді діяльності існують відповідні види активності: перетворювальна, пізнавальна, комунікативна. Кожен вид активності, що реалізується у відповідній діяльності, також буде мати свою специфіку.

Нами ініційовано і проведено дослідження стану розвитку мовленнєвої активності дітей старшого дошкільного віку. Розробляючи завдання психолінгвістичного дослідження, ми передбачили, що виявлення мовленнєвопасивних дітей передбачає необхідність задіяти експрес-оцінку рівня мовленнєвого розвитку. 3 одного боку, психолінгвісти Л.В. Засєкіна, С.В. Засєкін визначають важливі аспекти дослідження мовленнєвої генези дітей дошкільного віку, а саме: кількість слів у монологічному та діалогічному мовленні дитини 3 різною кількістю складів, довжина діалогів, сформованість фонетичних, лексичних і граматичних навичок та аналіз пауз у мовленні дітей (Засєкіна \& Засєкін, 2008). 3 іншого, існуючі в психолінгвістичному арсеналі дослідників опитувальники, націлено на отримання максимальної інформації про дитину. Проте робота з ними займає тривалий час, вони заповнюються батьками, отже, у більшості випадків отримані дані $є$ результатом суб'єктивної оцінки, що є їх недоліком. Найбільш дотичними до нашого дослідження є результати лінгвістичної теорії особистості (Dijk van, 1997), які ним було застосовувано під час вивчення дискурсу письменників у руслі лінгвістичного аналізу тексту. 
Цікавим виявилися підходи науковця до процесів міжособистісної комунікації та особливостей їх моделювання. Нами також з'ясовано, що, на жаль, у зарубіжних наукових джерелах немає комплексної діагностики виявлення мовленнєвої пасивності в дітей старшого дошкільного віку.

Метою дослідження була оцінка стану розвитку мовленнєвої активності дітей основі даних діагностики. Рівень розвитку мовленнєвої активності дітей оцінювався за такими критеріями: розуміння мовлення дорослих, власне мовленнєвий розвиток дітей, який охоплює комунікативні вміння і навички, пізнавальна активність і предметно-практична діяльність дітей.

Нами було визначено рівні мовленнєвої активності дітей: високий рівень - мовленнєва активність, середній рівень - часткова мовленнєва активність, початковий рівень - мовленнєва пасивність, критичний рівень - повна відсутність мовленнєвої активності, або мутизм. Із 68 респондентів із критичним рівнем не виявлено. За результатами констатації розподіл дітей за визначеними рівнями має такий вигляд: високий рівень - 3,0\% дітей; 55,0\% - діти середнього рівня мовленнєвої активності. 42,0\% респондентів нами віднесено до третього, початкового, рівня активності. Далі нами було виокремлено у цій віковій категорії три типологічні групи мовленнєвопасивних дітей, а саме:

1) група "операціонально-технічної»

мовленнєвої nacuвності, основу якої складають: невміння i небажання дитини використовувати мовленнєві навички під час спілкування. Так, на мовленнєвому занятті діти за допомогою вихователя складали розповідь - опис лелеки за схемою. В повсякденному житті на пропозицію дорослого описати горобчика або синичку, які прилетіли до годівнички, дитина відмовляється від спілкування або складає 2-3 простих речення, констатуючи дії птахів. Таких дітей у типологічній групі було $57,0 \%$.

2) група «мотиваџійної» мовленнєвої пасивності, для якої характерні: незацікавленість дитини в мовленнєвій діяльності. Однією 3 причин, на наш погляд, $є$ суб'єктивно-пасивна роль дитини під час одержання мовленнєвої інформації від дорослого (педагога, батьків). Це яскраво виявляється під час мовленнєвих занять, коли вихователь, намагаючись якомога більше запропонувати пізнавального матеріалу, забуває, хто на занятті повинен бути 
Overcoming Communicative Deadaptation of Speech Passive...

мовленнсво-активним. $\quad$ У цій групі нами визначено $21,0 \%$ респондентів.

3) група «часткової» або «вибіркової» мовленнєвої пасивності. Старші дошкільники, яких ми умовно віднесли до цієї групи дітей, виявляли мовленнєву пасивність тільки в окремих видах роботи: 3 граматики або фонетики. Дітей із «вибірковою» мовленнєвою пасивністю нами зареєстровано 22,0\%.

Слід зазначити, що симптоми мовленнєвої пасивності, які належать різним групам, можуть проявлятися одночасно і в однієї дитини. Також пасивність може мати i різні ступені проявів: від яскравої, демонстративної, до прихованої (замаскованої). Зрозуміло, що наведена класифікація мовленнєвої пасивності не має категоричного характеру - іiі межі рухливі.

\section{Висновки}

Аналіз теоретичних підходів до проблеми дає підстави визначити кілька загальних закономірностей, характерних для дітей дошкільного віку 3 мовленнєвою пасивністю: діти не вміють (не хочуть) звертатися із проханнями до однолітків або дорослих; не вміють привернути увагу співрозмовника (для цього використовується або фізична сила, або жести); часто відтворюють репліки товаришів (вихователів) без додаткової розумової переробки; будь-яке перемикання з одного виду діяльності на іншій супроводжується своєрідним емоційним «вибухом».

Доведено, що порушення процесу спілкування у мовленнєвопасивних дошкільників виявляється переважно у таких двох різновидах, як комунікативний дефіuит (гіпокомунікативність із заниженою цікавістю до довкілля, уповільненням налагодженням вербальних i невербальних контактів, відсутністю прагнення висловити свої бажання вокалізацією, поглядом, мімікою чи жестами), або, навпаки, комунікативна екзальтачія (надлишкова гіперемоційність у контактах, «прилипливість», конфліктність, розгальмованість). В обох різновидах порушена мотиваційна складова мовленнєвого спілкування, але у більшості випадків потерпає і сама можливість цього акту. 


\section{Література}

Альбуханова-Славская, К.А. (1991). Стратегия жизни. Москва: Мысль.

Белякова, Л.И. (1992). Проблемный подход к анализу патогенетических механизмов заикания. Заикание: проблемы теории и практики (с. 3-20). Москва.

Волочков, А.А. (2003). Активность субъекта и развитие учащзегося: теория, диагностика и проблемь развивающих технологий. Пермь: Издательство ПОИПКРО.

Выготский, Л.С. (1996). Психология развития как феномен культуры: избран. nсихол. трудыл. Москва-Воронеж: МОДЭК.

Горелов, И.Н., \& Седов, К.Ф. (1998) Основы психолингвистики. Москва: Лабиринт.

Джидарьян, И.А. (1988). Категория активности и ее место в системе психологического знания. Категории материалистической диалектики 6 психологии (с. 56-87). Москва: Наука.

Засєкіна, Л.В., \& Засєкін, С.В. (2008). Психолінгвістична діагностика. Луцьк: РВВ «Вежа».

Зданевич, Л.В. (2013). Професійна підготовка майбутніх вихователів до роботи з дезадаптованими дітьми: теорія і методика. (Монографія). Хмельницький: Вид-во ХГПА.

Каган, М.С. (1974). Человеческая деятельность: опыт системного анализа. Москва: Политиздат.

Калмикова, Л.О. (2009). Психолінгвістичні принципи формування мовленнєвої діяльності в дітей старшого дошкільного віку. Психолінгвістика, 3, 54-60.

Ковалев, А.Г. (1970). Психология личности. Москва: Просвещение.

Крутій, К.Л. (2003). Методика проведення індивідуальних занять із мовленнєвопасивними дітьми дошкільного віку. Запоріжжя: ТОВ «ЛІПС Лтд».

Крутій, К.Л. (2005). Діагностика мовленнєвого розвитку дітей дошкільного віку. (Монографія). Запоріжжя : ТОВ «ЛІПС» ЛТД.

Леонтьев, А.А. (2003). Язык и речевая деятельность в общей и педагогчческой психологии: изб. психол. труды. Москва: Изд-во Московского психологосоциального института; Воронеж: Изд-во НПО «МОДЭК».

Леонтьев, А.А. (2005). Основы психолингвистики. Москва: Смысл.

Мастюкова, Е.М. (1981). Онтогенетический подход к структуре дефекта при моторной алалии. Дефектология, 6, 21-26.

Медведева, Е.Ю. (2003). Особенности коммуникативной дезадаптации и ее коррекция у детей с задержкой речевого развития в пятилетнем воздасте. Дисс. канд. псих. наук. Нижний Новгород.

Слободчиков, В.И. (2010) Понятие нормы. Школьный психолог, 2.

Смирнова, Е.О. (1989). Соотношение представлений о себе и других дошкольников. Нов. исследования в психологии и возрастной физиологии, 2, $66-70$.

Трошин, О.В. (2000). Задержка нервно-психического развития. Вестник психолого-педагогического факультета, 2, 45-49.

Ушакова, Т.Н. (2008). Узловые проблемы речеязыкового развития ребёнка. Речь ребёнка: Проблемы и решения (с. 13-39). Москва: Изд-во «Институт психологии РАН». 
Фельдштейн, Д.И. (1999). Психология взросления: структурно-содержательные характеристики проиесса развития личности: изб. труды. Москва: Флинта.

Русанівський, В.М. (Ред.). (1972). Філософські питання мовознавства. Київ: Наукова думка.

Рубинштейн, С.Л. (2000). Основы общей психологии. Санкт-Петербург: «Питер».

Ahmadian, M.J. (2016). Task-based language teaching and learning. Language Learning Journal, 44(4), 377-380. https://doi.org/10.1080/09571736.2016.1236523

Dijk, van TA. (1997). The study of discourse. Discourse as structure and process (pp. 1-34). London: SAGE Publications.

Lanvers, U. (2017). Language learning motivation, Global English and study modes: A comparative study. Language Learning Journal, 45(2), 220-244. https://doi.org /10.1080/09571736.2013.834376

Foster-Cohen, Susan H. (2014). An Introduction to Child Language Development. Learning about Language. London: Routledge. https://doi. org/10.4324/9781315844893

Kalmykova, L.O. (2015). Ontogenesis of the vocal activity of children of the sixth year of life. In H. Kyuchukov (Ed.), Acquisition of Slavic Languages (pp. 2953). Munich: Lincom.

\section{References}

Albukhanova-Slavskaya, K.A. (1991). Strategiya zhizni [Strategy of life]. Moscow: Mysl [in Russian].

Beliakova, L.I. (1992). Problemnyi podhod k analizu patogeneticheskikh mekhanizmov zaikaniya [Problem approach to the analysis of pathogenic mechanisms of stammer]. Zaikanie: problemy teorii i praktiki - Stammer: problems of theory and practice (pp. 3-20). Moscow [in Russian].

Volochkov, A.A. (2003). Aktivnost subekta $i$ razvitie uchaschegosya: teoriya, diagnostika $i$ problemyi razvivayuschih tehnologiy [Activity of a subject and development of a student: theory, diagnosis and problems of developing technologies]. Perm: Izdatelstvo POIPKRO [in Russian].

Vygotskyi, L.S. (1996). Psihologiya razvitiya kak fenomen kulturyi [Psychology of development as a cultural phenomenon]. Moscow-Voronezh: MODEK [in Russian].

Gorelov, I.N., \& Sedov, K.F. (1998). Osnovy psikholingvistiki [Foundations of psycholinguistics]. Moscow: Labirint [in Russian].

Dzhidaryan, I.A. (1988). Kategoriya aktivnosti i yee mesto v sisteme psikhologicheskogo znaniya [Category of activity and its place in the system of psychological knowledge]. Kategorii materialisticheskoy dialektiki v psihologii Categories of materialist dialectic in psychology (pp. 56-87). Moscow: Nauka [in Russian].

Zasjekina, L.V., \& Zasjekin, S.V. (2008). Psiholingvistichna diagnostika [Psycholinguistic diagnostics]. Luck: RVV «Vezha» [in Ukrainian].

Zdanevych, L.V. (2013). Profesiina pidhotovka maibutnikh vykhovateliv do roboty $z$ dezadaptovanymy ditmy: teoriia $i$ metodyka [Professional training of the future kindergartners to work with deadapted children]. Khmelnytskyi: Vyd-vo KhHPA [in Ukrainian]. 
Kagan, M.S. (1974). Chelovecheskaya deyatelnost: opyit sistemnogo analiza [Human activity: Experience of system analysis]. Moscow: Politizdat [in Russian].

Kalmykova, L.O. (2009). Psykholinhvistychni pryntsypy formuvannia movlennievoi diialnosti $\mathrm{v}$ ditei starshoho doshkilnoho viku [Psycholinguistic principles of forming speech activity of children of senior pre-school age]. PsykholinhvistykaPsycholinguistics, 3, 54-60 [in Ukrainian].

Kovalev, A.G. (1970). Psihologija lichnosti [Personality Psychology]. Moscow: Prosveshhenie [in Russian].

Kruty, K.L. (2003). Metodyka provedennia indyvidualnykh zaniat iz movlennievopasyvnymy ditmy doshkilnoho viku [Techniques of conducting individual classes with speech passive children of pre-school age]. Zaporizhzhia: TOV «LIPS Ltd» [in Ukrainian].

Kruty, K.L. (2005). Diagnostika movlennevogo rozvitku ditei doshkilnogo viku [Diagnosis of speech development of preschool children]. Zaporizhzhia: TOV «LIPS Ltd» [in Ukrainian].

Leontyev, A.A. (2003). Yazyk $i$ rechevaya deyatelnost $v$ obschei $i$ pedagogicheskoi psikhologii [Language and speech activity in general and pedagogical psychology]. Moscow: Izd-vo Moskovskogo psihologo-sotsialnogo instituta; Voronezh: Izd-vo NPO «MODEK» [in Russian].

Leontyev, A.A. (2005). Osnovy psiholingvistiki [Fundamentals of psycholinguistics]. Moscow: Smysl [in Russian].

Mastiukova, E.M. (1981). Ontogeneticheskii podkhod k strukture defekta pri motornoi alalii [Ontogenetic approach to the structure of defect at motor alalia]. Defectology - Defektologiya, 6, 21-26 [in Russian].

Medvedeva, E.Yu. (2003). Osobennosti kommunikativnoi dezadaptatsii i yee korrektsiya $\mathrm{u}$ detei $\mathrm{s}$ zaderzhkoi rechevogo razvitiya $\mathrm{v}$ piatiletnem vozraste [Peculiarities of communicative deadaptation and its correction of five-yearold children with the delay in speech development]. Candidate's thesis. Nizhnii Novgorod [in Russian].

Slobodchikov, V.I. (2010) Poniatiye normy [Concept of norm]. Shkolnyi psikholog School psychologist, 2 [in Russian].

Smirnova, E.O. (1989). Sootnosheniye predstavlenii o sebe i drugikh doshkolnikov [Relation of concepts about oneself and other pre-schoolers]. Nov. issledovaniya $v$ psikhologii $i$ vozrastnoi fiziologii - New researches in psychology and agerelated physiology, 2, 66-70 [in Russian].

Troshin, O.V. (2000). Zaderzhka nervno-psikhicheskogo razvitiya [Delay of neuropsychic development]. Vestnik psihologo-pedagogicheskogo fakulteta Bulletin of the Faculty of Psychology and Education, 2, 45-49 [in Russian].

Ushakova, T.N. (2008). Uzlovye problemy rechejazykovogo razvitija rebjonka [Key problems of the child's speech and language development]. Rech rebenka: Problemyi $i$ resheniya - Speech of a child: problems and solutions (pp. 13-39). Moscow: Izd-vo «Institut psihologii RAN» [in Russian].

Feldshtein, D.I. (1999). Psihologiya vzrosleniya: strukturno-soderzhatelnyie harakteristiki protsessa razvitiya lichnosti [Psychology of aging: structuralcontextual characteristics of the process of personality development]. Moscow: Flinta [in Russian].

Rusanivskyi, V.M. (Ed.). (1972). Filosofski pytannia movoznavstva [Philosophic questions of linguistics]. Kyiv: Naukova dumka [in Ukrainian]. 
Rubinshtein, S.L. (2000). Osnovy obshchei psikhologii [Fundamentals of general psychology]. Sankt-Peterburg: Piter [in Russian].

Ahmadian, M.J. (2016). Task-based language teaching and learning. Language Learning Journal, 44(4), 377-380. https://doi.org/10.1080/09571736.2016.1236523

Dijk, van TA. (1997). The study of discourse. Discourse as structure and process (pp. 1-34). London: SAGE Publications.

Lanvers, U. (2017). Language learning motivation, Global English and study modes: A comparative study. Language Learning Journal, 45(2), 220-244. https://doi.org $/ 10.1080 / 09571736.2013 .834376$

Foster-Cohen, Susan H. (2014). An Introduction to Child Language Development. Learning about Language. London: Routledge. https://doi. org/10.4324/9781315844893

Kalmykova, L.O. (2015). Ontogenesis of the vocal activity of children of the sixth year of life. In H. Kyuchukov (Ed.), Acquisition of Slavic Languages (pp. 2953). Munich: Lincom.

\section{АНОТАЦІЯ}

Вступ. У статmі проаналізовано мовлення дитини в його індивідуальних особливостях. Йдеться про становлення комунікативної компетенції дитини. 3'ясовано, що цей процес охоплює два аспекти: надбання навичок у системномовній і власне комунікативній сферах.

Мета - структурувати теоретичні розробки досліджуваної проблеми, акцентувати їх внесок у загальні підходи до мовленнєвої активності дошкільників, виокремити групи мовленнєво пасивних дітей за ознакою комунікативної дезадаптації.

Методи та методики дослідження. Виокремлено типологічні групи мовленнєво пасивних дітей: "операціонально-технічної», «мотиваційної», «часткової» або "вибіркової» мовленнєвої пасивності. Сплановано та здійснено експериментальне дослідження щодо виявлення мовленнєво пасивних дітей. Використано Ґейдельберзький тест мовленнєвого розвитку та опитувальник для оцінки мовленнєвого і когнітивного розвитку дитини.

Результати та дискусії. Індивідуальне мовлення дитини розуміється як соціально і біологічно обумовлена система знакових психічних конфігурацій, використана індивідом як для мислення, так і для мовленнєвого спілкування, яке може бути як активним, так і пасивним. 3'ясовано можливості використання результатів сучасних міжгалузевих досліджень для виявлення комунікативної дезадаптації у дітей старшого дошкільного віку, які є мовленнєво пасивними. Визначено мовленнєву активність дітей як стійку властивість особистості, що виявляється в здатності сприймати і розуміти мовлення оточуючих. Під мовленнєвою пасивністю дитини розуміємо знижений рівень мовленнєвої діяльності, зумовлений особливостями мовленнєвого розвитку в онтогенезі. Охарактеризовано активний та інертний типи мовлення. Зроблено висновок про те, що особливе значення для онтопсихолінгвістичних досліджень має вік п'яти років. Цей вік характеризується кризою егочентричного мовлення, 
що завершується його інтеріоризацією та супроводжується у цілому комунікативною дезадаптацією.

Висновки. Доведено, що порушення процесу спілкування у мовленнєво пасивних дошкільників виявляється переважно у таких двох різновидах, як комунікативний дефіцит або комунікативна екзальтація.

Ключові слова: діти дошкільного віку, мовленнєво пасивність, мовленнєва діяльність, комунікативна дезадаптація, комунікативна екзальтація, мовленнєвий і когнітивний розвиток дитини.

\section{Зданевич Лариса, Крутий Екатерина. Преодоление коммуникативной} дезадаптации у пассивно речевых детей дошкольного возраста

\section{АННОТАЦИЯ}

Вступление. В статье проанализирована речь ребенка в его индивидуальных особенностях. Речь идет о становлении коммуникативной компетенции ребенка. Выяснено, что этот процесс охватывает два аспекта: приобретение навыков в системно-языковой и собственно коммуникативной сферах.

Цель - структурировать теоретические разработки исследуемой проблемы, акцентируя их вклад в общие подходы к речевой активности дошкольников, выделить группы пассивно речевых детей по признаку коммуникативной дезадаптации.

Методы и методики исследования. Выделены типологические группы пассивно речевых детей: "операционально-технической», "мотивационной», «частичной» или «выборочной» речевой пассивности. Спланировано и осуществлено экспериментальное исследование по выявлению пассивно речевых детей. Использованы Гейдельбергский тест речевого развития и опросник для оченки речевого и когнитивного развития ребенка.

Результаты и дискуссии. Индивидуальная речь ребенка понимается как сочиально и биологически обусловленная система знаковых психических конфигураций, использована индивидом как для мышления, так и для речевого общения, которое может быть, как активным, так и пассивным. Выяснено возможности использования результатов современных межотраслевых исследований для выявления коммуникативной дезадаптации у детей старшего дошкольного возраста, которые является пассивно речевыми. Определено речевую активность детей как устойчивое свойство личности, проявляющееся в способности воспринимать и понимать речь окружающих. Под речевой пассивностью ребенка понимаем сниженный уровень речевой деятельности, обусловленный особенностями речевого развития в онтогенезе. Охарактеризованы активный и инертный типы речи. Сделан вывод о том, что особое значение для онтопсихолингвистических исследований имеет возраст пяти лет. Этот возраст характеризуется кризисом эгоцентрической речи, завершается его интериоризацией $и$ сопровождается в целом коммуникативной дезадаптацией. 
Overcoming Communicative Deadaptation of Speech Passive...

Выводы. Доказано, что нарушение процесса общения у пассивно речевых дошкольников проявляется преимущественно в таких двух разновидностях, как коммуникативный дефицит или коммуникативная экзальтация.

Ключевые слова: дети дошкольного возраста, пассивно речевые дети, речевая деятельность, коммуникативная дезадаптация, коммуникативная экзальтация, речевое и когнитивное развитие ребенка. 